\title{
GYốRI FERENC:* \\ A humánfejlettség és a szociokulturális háttér hatása a középiskolai eredményesség területi mutatóira
}

\begin{abstract}
As it has been proven by a lot of studies our career chances as well as our development mostly depend on the educational background. A factor of great importance in the process of talent development is the school. The destiny of the talented is basically influenced by their social circumstances. It gave me the idea to find relations between rates of achievement at school (result of entrance exams and of national competitions) and human development index (HDI) which expresses the social and territorial differences. The most important result is the level of human development influences the competition achievements in a stronger way than the results of entrance exams at colleges and universities.
\end{abstract}

\section{Bevezetés}

Általánosan elterjedt az a nézet, miszerint az oktatás arra való, hogy csökkentse a társadalmi, vagyoni, hatalmi különbségeket, lehetőséget nyújtson az egyének számára képességeik kibontakoztatására és tehetségükhöz méltó helyük megtalálására a társadalomban. A tény ezzel szemben az - mint arra számos oktatásszociológiai és pszichológiai vizsgálat utal -, hogy a közoktatás nem hogy nem csökkenti, sokkal inkább újratermeli, megszilárdítja a tanulók között fennálló társadalmi egyenlötlenségeket. A magyar közoktatás - elegendö csak a hazai MONITOR, PISA felmérések eredményeire, vagy az Oktatáskutató Intézet vizsgálataira utalnunk - sajnos az európai átlagot meghaladó mértékben fokozza a tanulók közötti esélyegyenlötlenséget, gátolva ezzel legnagyobb nemzeti eröforrásunk, a tehetség kiaknázását. E visszásságok már az egyenlőséget deklaráló szocialista tanügyi rendszerben is virulens módon léteztek és továbbélnek ma is dacára annak, hogy oktatási rendszerünk a rendszerváltást követően sok tekintetben átalakult. Sajnos az iskola - nemzetgazdaságunk ingatag helyzete, a romló demográfiai viszonyaink, az állam anyagi és erkölcsi felelösségvállalásának csökkenése, valamint pedagógiai kultúránk rugalmatlansága miatt - alapvetően nem tudott, nem tudhatott megújulni sőt, pesszimistább vélemények szerint, egyenesen csődbe jutott (Nagy 2005). A közép- és felsőfokú oktatás tömegesedése ellenére kedvezötlen társadalmi folyamatok játszódnak le, a státusmobilitás szükül, a kulturális reprodukció erősödik.

Az iskolai eredményességet - a szülöktőll öröklött adottságok leszámításával - a családi környezet és az iskola együttesen határozzák meg. Az iskolák tanulói összetételük, felszereltségük, tanári állományuk tekintetében, akár egy településen belül is, nagyon különbözhetnek egymástól. Sajátossá teszi öket földrajzi környezetük, településük demográfiai, vallási, etnikai összetétele, gazdasági és közigazgatási pozíciója is. A tanulók családjának vagyoni helyzete, társadalmi státusa és iskolai teljesítményük között kétséget kizáró kapcsolat mutatkozik. A szociológusok szerint kulturális újratermelésben a családon belül hasżnált nyelvi kódoknak és az iskolák ún. „rejtett tantervének” van kitüntetett szerepe (Giddens 1997). Mindebböl nyilvánvalóan következik: nem mindegy, hogy ki, hol, milyen családba születik, $s$ majdan hová, milyen iskolába jár.

\footnotetext{
- Doktorjelölt - Pécsi Tudományegyetem, Földtudományok Doktori Iskola; középiskolai tanár Dugonics András Piarista Gimnázium, Szeged.
} 
$\mathrm{Az}$ oktatás területi vetületében a humánfejlettség települési, sőt regionális különbségei is tetten érhetök. A jól szervezett gazdaságban az alapjogok az oktatásban is teljesülnek (Herendi 2009). De a hátrányos helyzetü, periférikus térségekben az iskolákra az átlagnál messze több teher rakódik: gyengébb anyagi és személyi feltételek mellett müködnek, s emellett lényegesen több energiát kell mozgósítaniuk tanulóik szocializációs és kulturális hiányainak pótlására, a visszahúzó hatások mérséklésére. Az oktatáskutatók tapasztalatai szerint a falusi iskolákból középfokra lépő fiatalok, a teljesítménykülönbségek miatt kudarcot szenvedve, könnyebben morzsolódnak le és szakképzettség megszerzése nélkül tovább gyarapitják a munkanélküliek táborát (M. Császár 2004).

\section{A versenyteljesitmények területi különbségei}

A kiépülő piacgazdaság mechanizmusai felértékelték a helyi és regionális sajátosságokat, ezzel együtt új regionális tagozódási rend alakult ki, szociális feszültségeket és éles esélykülönbségeket generálva. A rendszerváltozás elött az iskolák közötti különbségek még elsősorban a ,települési lejtö" mentén manifesztálódtak, míg ma a kedvezö, vagy kedvezőtlen jelenségek térségi, regionális szinten is tapinthatóvá váltak. $\mathrm{Ez}$ - egy tágabb összefüggésrendszerben - kapcsolatban állhat a jövedelemszerzés lehetőségeivel (Beluszky 1999). Jól láthatóan fokozódik ugyanis a föváros és a vidék közötti fejlettségbeli elkülönülés, valamint a nyugati régiók általános elönye a keletiekkel szemben. Az oktatási struktúra pedig a társadalmi tér többi struktúrájával szoros kölcsönhatásban változik. Funkcióinak térbeliségét ugyanazok regionális folyamatok, valamint központ-vonzáskörzet relációk alakítják, mint a többi funkcióét (Tóth J.-Pénzes I.-Béla D. 1973).

A területi fejlettség differenciáit a középiskolák régiónkénti eredményességi mutatói is tükrözik. Az iskolák valódi eredményességét, pedagógiai hozzáadott értékét természetesen lehetetlen a számok nyelvén kifejezni, hiszen az iskolák nevelési céljai nagyon különbözőek, felvett tanulóik szociokulturális háttere sokrétũ és a velük szemben támasztott társadalmi igények is igencsak mások. A tudás, a produkció összehasonlitására viszont megfelelönek tünnek a felvételi teljesitmények, valamint a különféle középiskolai versenyek eredményei (Neuwirth 2005).

A versenyek azért is élveznek számunkra prioritást, mert a rájuk való felkészités-felkészülés a tehetséggondozás egyik leghatékonyabb eszköze. A céltudatos munka, a fiatalon elsajátított kutatás-módszertani ismeretek, az önálló forráskereső, elemzö, gyüjtö- és alkotótevékenység nemcsak élményt nyújt a diákok számára, de jövőjüket is megalapozhatja. Évente több száz versenyen, több százezer tanuló mérheti össze tudását, így az iskolák versenyeredményességi mutatói az oktatás fontos kimeneti paramétereinek tekinthetök.

Az Országos Középiskolai Tanulmányi Verseny Országos Közoktatási Intézet által publikált adatait elemezve feltünik, hogy a versenyeken legjobban teljesítö, 1-3. helyezést elérö tanulók több mint fele rendre a közép-magyarországi régió középiskoláiból kerül ki, ami csaknem kétszerese az ott élök össznépességhez viszonyitott arányának. A többi régió közül egyedül a dél-alföldi és a nyugat-magyarországi iskolák részesedése tart lépést a népességi aránnyal, míg mások - különösen Észak-Magyarország és az Észak-Alföld jócskán alulreprezentáltak. Ugyanezt tanúsítják a korszerkezet torzító hatását kiküszöbölö, a középiskolás korú (15-19 éves) népességéhez viszonyított mutatók is, akár az első három, akár az első tíz OKTV helyezett eredményét vesszük alapul (Győri 2004).

A regionális mutatók azonban elsimítják az amúgy igen „beszédes” intraregionális különbségeket. A korcsoportos mutatók tekintetében az elsỏ és az utolsó megye közötti különbség csaknem hússzoros. Az eredményességi rangsort tetemes elönnyel Pest megye (a fövárossal) vezeti, melynek korcsoportos mutatója az országos átlag kétszerese. Jól mérhe- 
tố a megyei mutatókat ugyancsak meghatározó régióközpontok húzóereje is. A megyék közül a legjobb indexe - mind az 1-3., mind az 1-10. helyezés vonatkozásában - Csongrádnak, Györ-Moson-Sopronnak és Baranyának van. A sor végén a hagyományosan agrártermelést folytató, illetve strukturális gondokkal küzdő megyék, Somogy, Nógrád és Szabolcs-Szatmár-Bereg állnak. A differenciák okait feltáró elemzések a társadalmi környezet hatását valószínüsítik: a sikeresen szereplö tanulók aránya kapcsolatban áll a jövedelmi, foglalkoztatottsági és az iskolázottsági viszonyokkal.

A településméret és a településhierarchiában elfoglalt hely fontos tényezöként jelenik meg. A népesebb városok - különösen az egyetemi központok - fejlettebb infrastruktúrájú, állandó versenyhelyzetben lévő iskolái kedvezőbb lehetöségeket nyújtanak a versenyekre való felkészüléshez. A legjobbak négyötöde valamelyik megyeszékhely iskolájába jár (l. táblázat). A regionális központok kömyezetükben szinte egyeduralkodók. A leginkább „decentralizált” megyék Komárom-Esztergom és Tolna. Fontos azonban megjegyeznünk, hogy a megyeszékhelyek látványos mutatói mögött a legtöbb esetben csak az ún. „elit” iskolák sorakoznak.

1. táblázat. Az OKTV elsõ tíz helyezettjeinek megoszlása megyék és megyeszékhelyek szerint (1987-2001)

\begin{tabular}{|c|c|c|c|c|c|}
\hline \multirow[b]{2}{*}{ Megye } & \multirow[b]{2}{*}{$\begin{array}{c}\text { 1-10. } \\
\text { helyet } \\
\text { elértek } \\
\text { száma }\end{array}$} & \multirow{2}{*}{$\begin{array}{c}1-10 . \\
\text { helyezettek } \\
\text { országos } \\
\text { részesedése } \\
(\%)\end{array}$} & \multirow[b]{2}{*}{ Megyeszékhely } & \multicolumn{2}{|c|}{ A megyeszékhely } \\
\hline & & & & $\begin{array}{c}\text { 1-10. } \\
\text { helyezettjeinek } \\
\text { száma }\end{array}$ & $\begin{array}{c}\text { részesedése } \\
\text { a megye 1-10. } \\
\text { helyezettjeibó! } \\
(\%)\end{array}$ \\
\hline Bács-Kiskun & 184 & 3,6 & Kecskemet & 102 & 55,4 \\
\hline Baranya & 241 & 4,7 & Pécs & 222 & 92,1 \\
\hline Békés & 134 & 2,6 & Békéscsaba & 54 & 40,3 \\
\hline Borsod-Abaúj-Zemplén & 206 & 4,0 & Miskolc & 166 & 80,6 \\
\hline Csongrád & 305 & 5,9 & Szeged & 255 & 83,6 \\
\hline Fejér & $11 \overline{3}$ & 2,2 & Székesfehérvár & 95 & 84,1 \\
\hline Györ-Moson-Sopron & 293 & 5,7 & Győr & 157 & 53,6 \\
\hline Hajdú-Bihar & 262 & 5,1 & Debrecen & 245 & 93,5 \\
\hline Heves & 94 & 1,8 & Eger & 77 & 81,9 \\
\hline Jász-Nagykun-Szolnok & 120 & 2,3 & Szolnok & 62 & 51,7 \\
\hline Komárom-Esztergom & 124 & 2,4 & Tatabánya & 4 & 3,2 \\
\hline Nógrád & 28 & 0,5 & Salgótarján & 20 & 71,4 \\
\hline Pest megye & 2459 & 47,9 & Budapest & 2214 & 90,0 \\
\hline Somogy & 70 & 1,4 & Kaposvár & 43 & 61,4 \\
\hline Szabolcs-Szatmár-B. & 66 & 1,3 & Nyíregyháza & 52 & 78,8 \\
\hline Tolna & 89 & $\overline{1,7}$ & Szekszárd & 25 & 28,1 \\
\hline Vas & 91 & 1,8 & Szombathely & 60 & 65,9 \\
\hline Veszprém & 139 & 2,7 & Veszprém & 60 & 43,2 \\
\hline Zala & 111 & 2,2 & Zalaegerszeg & 67 & 60,4 \\
\hline Osszesen: & 5129 & 100,0 & Osszesen: & 3980 & Atlag: 77,6 \\
\hline
\end{tabular}

Adatok forrása: http://elnok79.elte.hu/verseny/oktv9v.hts. A szerzó saját számitása.

\section{Magasabb humánfejlettség - eredményesebb tanulók?}

$\mathrm{Az}$ új tudás létrehozása, átvitelének gyorsasága, vagy alkalmazásának hatékonysága egyaránt az emberek képességein múlik. E képességek megszerzése elsődlegesen az oktatás-képzési rendszerben történik, vagyis nem mindegy, hogy az iskolapadból kikerülök milyen kompetenciákkal rendelkeznek. Joggal feltételezhetjük, hogy a humánfejlettség kölcsönhatásban áll a középiskolák ,kimeneti” mutatóival. Ennek feltárása céljából a szocioökonómiai és szociokulturális fejlettséget egyaránt érintő humánfejlettségi mutatók 
(HDI), valamint az iskolák kimeneti mutatóinak (felvételi, verseny- és nyelvvizsgaeredmények) kapcsolatát kutattam (Györi 2007).

A háromféle versenymutató (Országos Középiskolai Tanulmányi Verseny, Országos Szakmai Tanulmányi Verseny, egyéb versenyek) segítségével, a HDI mintájára képzett megyei versenyindexek (TVI) markáns területi eltéréseket jeleznek (1. ábra). Az ábrán kirajzolódik északi megyéink lemaradása, valamint a föváros, Nyugat-Magyarország, a fejlettebb alföldi megyék és Baranya megye elönye.

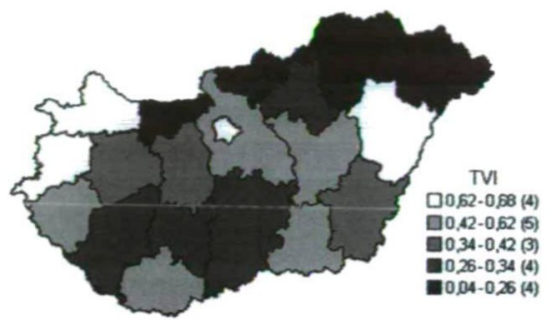

\section{1. ábra. A komplex tanulmányi versenyindex alakulása megyénként a 2000-2004 közötti időszak adatainak felhasználásával (a megyék átlaga $=0,39$ ) \\ (Forrás: A szerző saját szerkesztése)}

Hasonló módszerrel, de két komponens segítségével (felvételi arány, irásbeli dolgozatok átlagai) létrehozott megyei felvételi indexek (FEI) némiképp eltérö területi mintázatot jelenítenek meg (2. ábra). Itt olyan megyék is jól teljesítenek, melyek a versenyeredmények tekintetében a lemaradók között vannak (pl. Szabolcs-Szatmár-Bereg, Bács-Kiskun és Tolna megye). A verseny- és felvételi indexek nincsenek egymással szoros kapcsolatban. Joggal vetődik fel a kérdés, hogy a HDI melyik kimeneti mutatót támogatja jobban, ill. együtt változik-e valamelyikkel.

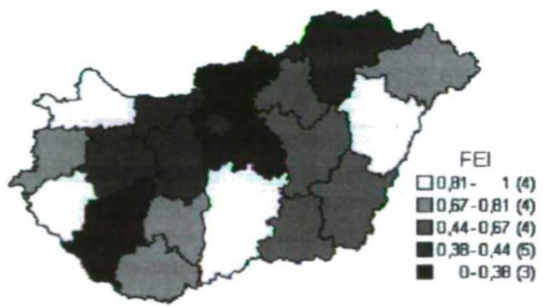

2. ábra. A komplex felvételi index alakulása megyénként a 2000-2004 közötti időszak adatainak felhasználásával (a megyék átlaga $=0,57$ )

(Forrás: A szerző saját szerkesztése)

Tekintettel a humánfejlettségi index számításánál figyelembe vett mutatók esetleges eltéréseire, a verseny- és felvételi indexeket két megyei szintü HDI-adatsorral is összefüggésbe hoztam (Rechnitzer-Smahó 2005, Nagy 2006). Kiderült, hogy a humánfejlettségi mutatók a versenyeredményekkel és a nyelvvizsga megszerzésével állnak kapcsolatban, ezzel szemben alig befolyásolják a felvételi teljesítményeket (2. táblázat).

A humánfejlettség tehát minden bizonnyal hat a tehetség első szárnypróbálgatásainak felfogható versenyeredményekre. Feltételezhető, hogy fejlettebb társadalmi-gazdasági környezetben könnyebben bontakozik ki a versenyszellem, a kreativitás, az alkotókedv, s 
ehhez az itt müködö iskoláknak is alkalmazkodniuk kell. Ugyanakkor a gyengébben fejlett térségek iskoláival szemben a fö kívánalom mindenekelött a sikeres felvételi, hiszen ez nyújt perspektivát, ez a mobilitás biztositéka. A vizsgálatok szerint számos kisvárosi iskola fordít nagy gondot a felvételi elökészitésére, de nemigen szorgalmazza tanulói versenyeztetését (Györi 2009). Természetesen kivételek mindig akadnak, s azt sem szabad elfelejtenünk, hogy a kiemelkedő tanulói teljesítmények mögött a legtöbb esetben elkötelezett, törödö, szakmájuk iránt rajongó pedagógusok állnak.

Bizonyosra vehető, hogy középiskoláink jó része a gyengébb humánfejlettségü térségekből is képes tanulóit a felsöoktatásba juttatni. Mindemellett az is valószinüsithető - erre vonatkozóan még nem készültek számitások -, hogy a különbözö, elit és nem elit egyetemi szakokra történő bekerülést a humánfejlettség eltérő mértékben befolyásolja. Ugyancsak tanulságos volna kideríteni, hogy a felsőoktatásra való felkészülést hol, milyen mértékben támogatja az iskolákkal szimbiózisban élő „szürke” iskolarendszer (nem iskolai szervezésü felkészítők, magán-, ill. különórák).

2. táblázat. A humán fejlettségi mutató, valamint a felvételi és tanulmányi versenyeredmények korrelációs együtthatói

\begin{tabular}{|l|l|c|c|}
\hline & \multicolumn{1}{|c|}{1.} & 2. & 3. \\
\hline \multirow{4}{*}{ A humán fejlettségi mutató (HDI) és } & az OKTV index között & 0,70 & 0,66 \\
\cline { 2 - 5 } & az OSZTV index között & 0,56 & 0,34 \\
\cline { 2 - 5 } & az egyéb versenyek indexe között & 0,35 & 0,26 \\
\cline { 2 - 5 } & $\begin{array}{l}\text { a komplex tanulmányi versenyindex } \\
\text { között }\end{array}$ & 0,72 & 0,55 \\
\cline { 2 - 5 } & a felvételi arány indexe között & $-0,05$ & $-0,29$ \\
\cline { 2 - 5 } & az irásbeli dolgozatok indexe között & 0,31 & 0,16 \\
\hline & a komplex felvételi index között & 0,13 & $-0,10$ \\
\cline { 2 - 5 } & a nyelwizsga index között & 0,71 & 0,73 \\
\hline
\end{tabular}

1. 2000-2004 átlagos, Neuwirth G. (2005) adatai alapján számitott értékei; 2. A HDI 2001. évre számított értékei szerint (Rechnitzer J.-Smahó M. 2005); 3. A HDI 2004. evre számitott értékei szerint (Nagy G. 2006) - A szerzó saját számitása.

\section{Irodalomjegyzék}

Beluszky P. (1999): Adalékok az alfôldi városhálózat 1990 utáni változásaihoz. Alföldi Tanulmányok, Békéscsaba, 17. pp. 30-51.

Giddens (1997): Szociológia, Osiris, Budapest, pp. 414-433.

Györi F. (2004): A régióközpontok szerepe a tehetségeloszlásban Magyarországon - In: Csapó T. et al. (szerk.): A településföldrajz helyzete és föbb kutatási irányai az ezredforduló után, BDF Társadalomföldrajz Tanszék, Szombathely, pp. 182-193.

Györi F. 2007 Tehetségföldrajz - humán fejlettség és az iskolai teljesítmények - In: Gulyás L. (szerk.): Régiók a Kárpát-medencén innen és túl. Eötvös József Föisk., Baja, pp. 248-252.

Gyốri $F$. (2009): A középfokú oktatás eredményességének területi különbségei a Dél-Alföldön, különös tekintettel a határ menti térségre. Közép-Európai Közlemények, 2., 4-5., pp. 49-56.

Herendi I. (2009): Kevesebb tanuló, kevesebb iskola? A kistelepülések kisiskoláit érintő változások. Közép-Európai Közlemények, 2., 4-5., pp. 57-63.

Nagy G. (2006): Divergencia, vagy konvergencia - Az átmenet gazdasági térfolyamatainak mérlege földrajzos szemmel, MTA FKI ATI, Békéscsaba, Kézirat.

Nagy J. (2005): A hagyományos pedagógiai kultúra csődje. Iskolakultúra, 6-7. melléklete, 9 p.

Neuwirth G. (2005): A középiskolai munka néhány mutatója 2004. OKI, Budapest, 173 p.

M. Császár Zs. (2004): Magyarország oktatásföldrajza. Pro Pannónia Kiadó, Pécs, 162. old.

Rechnitzer J.-Smahó M. (2005): A humán eröforrások regionális sajátosságai az átmenetben. MTA Közgazdaságtudományi Intézet, Budapest, 83 p.

Tóth J.-Pénzes I.-Béla D. (1973): A Dél-Alföld oktatási központjainak hierarchiája és vonzáskörzetei. Földrajzi Értesítő, 22. 2-3. pp. 289-297. 